\title{
SFPQ/TFE3 Fusion Gene
}

National Cancer Institute

\section{Source}

National Cancer Institute. SFPQ/TFE3 Fusion Gene. NCI Thesaurus. Code C99690.

A fusion gene that results from a chromosomal translocation $t(X ; 1)(p 11.2 ; p 34)$ which

fuses almost the entire coding sequence of the SFPQ gene to the 3 ' half of the TFE gene.

This fusion is associated with renal cell carcinoma. 